\title{
Repeated colonization of caves leads to phenotypic convergence in catfishes (Siluriformes: Trichomycterus) at a small geographical scale
}

\author{
Juan Sebastián Flórez ${ }^{1}$, Carlos Daniel Cadena² ${ }^{2}$ Carlos DoNascimiento ${ }^{3}$, Mauricio Torres ${ }^{1,4^{*}}$ \\ $5 \quad{ }^{1}$ Escuela de Biología, Universidad Industrial de Santander, Bucaramanga, Colombia \\ ${ }^{2}$ Departamento de Ciencias Biológicas, Universidad de los Andes, Bogotá, Colombia \\ ${ }^{3}$ Colecciones Biológicas, Instituto de Investigación de Recursos Biológicos Alexander von Humboldt, Villa de \\ Leyva, Colombia \\ ${ }^{4}$ Current address: Fundación Iguaque, Bucaramanga, Colombia \\ $10 \quad{ }^{*}$ Corresponding author. E-mail: mauriciotorres@iguaque.org
}

Short running title: Repeated catfish colonization of Colombian caves

\section{ABSTRACT}

Across various animal groups, adaptation to the extreme conditions of cave environments has resulted in convergent evolution of morphological, physiological, and behavioral traits. We document a Neotropical cave fish system with ample potential to study questions related to convergent adaptation to cave environments at the population level. In the karstic region of the Andes of Santander, Colombia, cave-dwelling catfishes in the genus Trichomycterus exhibit variable levels of reduction of eyes and body pigmentation relative to surface congeners. We tested whether cave-dwelling, eye reduced, depigmented Trichomycterus from separate caves in Santander were the result of a single event of cave colonization and subsequent dispersal, or of multiple colonizations to caves by surface ancestors followed by phenotypic convergence. Using mitochondrial DNA sequences to reconstruct phylogenetic relationships of Trichomycterus from Santander, we found that caves in this region have been colonized independently by two separate clades. Additional events of cave colonization -and possibly recolonization of surface streams- may have occurred in one of the clades, where surface and cave-dwelling populations exhibit shallow mtDNA differentiation, suggesting recent divergence or divergence in the face of gene flow. We also identified various taxonomic challenges including both a considerable number of potentially undescribed species and likely problems with the circumscription of named taxa. The system appears especially promising for studies on a wide range of ecological and evolutionary questions.

Keywords: adaptation, Andes, Colombia, freshwater fish, karstic, Neotropics, phylogeny. 


\section{INTRODUCTION}

Animals living in caves have long been of interest for the study of adaptation by natural selection and evolutionary convergence (Juan et al., 2010). Across various groups -including insects in different orders, arachnids, crustaceans and several vertebrates- adaptation to the extreme conditions of cave environments has resulted in multiple instances of convergent evolution involving a variety of morphological, physiological, and behavioral traits (Jeffery, 2001; Romero, 2011; Protas et al., 2011; Christiansen, 2012). Some of the most striking examples of convergent evolution are found in cave-dwelling fishes of various distantly related lineages, which have consistently lost eyes and body pigmentation in comparison to their surface-living relatives (Proudlove, 2010; Borowsky, 2018; Niemiller et al. 2019).

Convergent evolution resulting from adaptation to cave environments has also been observed at the population level in fishes, with a notable example being the Mexican Tetra, Astyanax mexicanus (De Filippi, 1853), a wellstudied taxon in which polyphyletic cave populations have reduced eyes and pigmentation, as well as unique aspects of metabolism and behavior, compared to closely related surface populations of the same species (Espinasa \& Borowsky, 2001; Yoshizawa et al., 2010; Kowalko et al., 2013; Moran et al., 2015; Riddle et al., 2018). Despite their striking phenotypic differences, surface and cave populations of $A$. mexicanus are connected by gene flow, suggesting that divergence in cave specialists has been driven and maintained by selection counteracting the homogenizing effects of migration (Bradic et al., 2012; Herman et al., 2018). The Mexican Tetra has emerged as

50 a model system to study the genetic and epigenetic basis of adaptation (Jeffery, 2001, 2009; Gross, 2012; Rohner et al., 2013; Gross et al., 2015; Gore et al., 2018); whether insights from the Mexican Tetra system have broad applicability to other clades adapting to caves, however, remains an open question. We here document a Neotropical cave fish system with ample potential to study questions related to adaptation to cave environments at the population level, and more broadly to test for convergence and to assess the repeatability of evolution by natural selection (Blount et al., 2018).

The Eastern Cordillera of the Andes of Colombia harbors a vast karst (i. e. limestone) region with hundreds of caves, most of them in the Department of Santander (Muñoz-Saba et al., 2013). Recent biological explorations of caves in this region have documented a wide diversity of animals restricted to cave environments, several of them endemic, including crabs, arachnids, and fishes (Campos, 2017; Villareal \& García, 2016; Mesa et al., 2018). Among the most peculiar organisms reported in these caves are seven species of catfishes in the genus Trichomycterus Valenciennes, 1832, which coexist regionally with 12 surface species of the same genus occurring in open streams (Ardila-Rodriguez, 2007; 2018; Castellanos-Morales, 2018; Castellanos-Morales et al., 2011; Mesa S. et al., 2018; Fig. 1; Table 1). Cave-dwelling species of Trichomycterus show a variable degree of reduction of eyes and body pigmentation relative to surface species; some subterranean species are pigmented and have small eyes, whereas other species lack eyes entirely and are totally depigmented. In addition, the degree of eye atrophy may vary within species, among different caves (Ardila-Rodríguez, 2006; Castellanos-Morales, 2007; 2008; 2010; 2018).

Two alternative evolutionary scenarios may explain the existence of cave-dwelling Trichomycterus in separate caves in Santander and their phenotypic similarity involving eye atrophy and depigmentation. First, cave specialists may be the result of a single event of cave colonization, adaptation to cave environments, and subsequent subterranean vicariance or dispersal leading to their currently disjunct distributions. Alternatively, multiple colonizations to caves by surface ancestors followed by evolutionary convergence towards cave-adapted phenotypes may have occurred. We here address these alternative hypotheses using a phylogenetic approach.

Previous phylogenetic studies of the family Trichomycteridae have considered only two cave species, both from Santander: Trichomycterus sandovali Ardila-Rodríguez, 2006 was sampled by Ochoa et al. (2017, 2020) whereas T. rosablanca Mesa, Lasso, Ochoa \& DoNascimiento, 2018 was included in analyses by Mesa S. et al. (2018). Because in those studies each cave species was independently found to be sister to the surface species Eremophilus mutisi Humboldt, 1805, it is possible that T. sandovali and T. rosablanca are close relatives, which would imply a single cave colonization event by Trichomycterus in Santander. However, available information is insufficient 80 to reach such a conclusion owing to limited geographic and taxonomic sampling. Our field work in streams and caves of Santander and new sequence data generated from recently collected specimens from multiple localities in Colombia allows for a first robust test of hypotheses posed to explain the evolution of the group. 


\section{MATERIAL AND METHODS}

\section{Study System}

Trichomycterus is one of the most taxonomically challenging groups of Neotropical fishes. The genus comprises 170 species (half the richness of its family Trichomycteridae; Fricke et al., 2019) ranging from Costa Rica to northern Patagonia. Species of Trichomycterus inhabit lowland to mountain freshwater streams, with an important fraction of its taxonomic diversity concentrated in the Colombian Andes (DoNascimiento \& Prada Pedreros, 2020). To date, 12 species living in cave environments have been described from disjunct regions including Bolivia (1 species), Brazil (3), Venezuela (1), and especially the Eastern Cordillera of Colombia (Fig. 1; Bichuette \& Rizzato, 2012; Ardila-Rodríguez. 2018; Castellanos-Morales, 2018; Mesa S. et al., 2018). Trichomycterus is considered a non-diagnosable, non-monophyletic taxon where species failing to meet diagnoses for other genera are often placed (Ochoa et al., 2017; Katz et al., 2018; Ochoa et al., 2020). One of the main issues complicating the taxonomy of Trichomycterus is their simplified morphology, which features relatively few characters to work with. However, a recent analysis using data from multiple genes partly clarified phylogenetic relationships in the genus, sorted species into clades largely matching large-scale geographical distributions, and made available hundreds of sequences to be employed in additional analyses (Ochoa et al., 2017). We here capitalize on these existing data complemented with newly generated sequences from specimens we collected to test hypotheses about evolution in cave environments in Colombia.

\section{Sampling}

Cave and surface trichomycterids have been found along the karstic landscapes of the Eastern Cordillera of Colombia in several departments (Castellanos-Morales \& Galvis, 2012; DoNascimiento et al., 2017). As a first approximation to this complex system, we focused our sampling efforts in the department of Santander, the region with the most extensive limestone rocks; such rocks are part of the Cumbre, Rosablanca, Paja, and Tablazo geological formations (aged from early to mid Cretaceous; Gaona-Narváez 2015; Gómez-Tapia et al., 2015). In Santander, meteoric and erosional processes have resulted in a karstic landscape with hundreds of caves spread in a relatively small area ( $\sim 170 \mathrm{~km}$ across), which remain largely unexplored (Mendoza et al., 2009, Muñoz-Saba et al., 2013).

110 We sampled populations of Trichomycterus catfishes in caves and surface streams, seeking to collect specimens from caves and adjacent streams whenever possible (Table 1). We collected 49 specimens from several populations in 2017, using hand nets or electrofishing (Samus-725 M), following methods for cave fish sampling proposed by Muñoz-Saba et al. (2013). Fishes were photographed, euthanized by immersion in roxicaine, and preserved in $96 \%$ ethanol. Taxonomic identification of specimens was based on comparison with original descriptions and geographic correspondence with type locality of nominal species, followed by comparative morphological examination of specimens available at the Freshwater Fish Collection of the Instituto Alexander von Humboldt (IAvH-P). For nomenclature, we followed recommendations by DoNascimiento \& Prada-Pedreros (2020) regarding synonimization of some recently described taxa from Santander. All samples were deposited at IAvHP. We also analyzed specimens collected in different drainages in Santander in 2018 during the "Santander Bio" expeditionary project (Torres \& Quiñones, 2019), several of which likely correspond to undescribed species of Trichomycterus (Table 1). Our sampling also included Nematogenys inermis (Nematogenyidae), Copionodon pecten (Copionodontinae), and Trichogenes longipinnis (Trichogeninae), which we included as outgroups for phylogenetic analyses based on previous studies (Ochoa et al., 2017; Ochoa et al., 2020).

\section{DNA Extraction and Sequencing}

We used sequences of the mitochondrial COI gene to reconstruct the phylogenetic relationships of Trichomycterus from Santander. This rapidly evolving marker was one of the genes used by Ochoa et al. (2017) to reconstruct the phylogeny of Trichomycteridae. We extracted total genomic DNA from the right pelvic fin using a phenol chloroform - isoamyl alcohol protocol (Wasko et al., 2003). We amplified a 652-bp segment of the COI mitochondrial gene using primers FishF1 and FishR1 (Ward et al., 2005). We conducted PCRs in a volume of $25 \mu \mathrm{l}$, containing $2.5 \mathrm{\mu l}$ of Buffer 10X, $1.5 \mu \mathrm{l} \mathrm{of} \mathrm{MgCl}_{2}(50 \mathrm{mM}), 0.5 \mu \mathrm{l}$ of dNTPs $(10 \mathrm{mM}), 0.2 \mu \mathrm{lof} \mathrm{Taq}$ Polymerase $(5 \mathrm{U} / \mathrm{\mu l}), 1.25 \mu \mathrm{l}$ of each primer, $1 \mu \mathrm{l}$ of BSA $(0.066 \mathrm{mM}), 4 \mu \mathrm{l}$ of template DNA, and $12.8 \mu \mathrm{l}$ of $\mathrm{ddH}_{2} 0$. The cycling included an initial denaturation at $94^{\circ} \mathrm{C}$ for $120 \mathrm{~s} ; 34$ cycles of denaturation at $94^{\circ} \mathrm{C}$ for $240 \mathrm{~s}$, 
annealing at $54^{\circ} \mathrm{C}$ for $30 \mathrm{~s}$, hybridization at $72^{\circ} \mathrm{C}$ for $45 \mathrm{~s}$; and extension at $72^{\circ} \mathrm{C}$ for $600 \mathrm{~s}$. PCR products were sequenced at Macrogen Inc. and the sequencing facilities of the Universidad de Los Andes (Bogotá, Colombia), resulting 41 COI gene sequences, which we visualized, edited, and aligned using the MUSCLE algorithm (Edgar, 2004) in Geneious v. 10.1.3 (Kearse et al., 2012). Combining our new data with existing sequences resulted in alignment comprising a total of 74 sequences (Table 1).

\section{Phylogenetic Analysis}

140 We used Bayesian inference as implemented in MrBayes v. 3.2.6 (Huelsenbeck \& Ronquist, 2001) and maximum likelihood in RAxML v. 8.2.10 (Stamatakis, 2014) to infer gene trees based on COI sequences. Bayesian analyses were conducted under the $\mathrm{GTR}+\mathrm{I}+\mathrm{G}$ model of nucleotide substitution, identified as the best-fit to the COI data as per the Akaike Information Criterion in PartitionFinder v. 2.1.1 (Lanfear et al., 2012). We ran 30 million generations, with two runs of four independent MCMC chains (three heated, one cold), sampling trees every 1000 generations, with $25 \%$ of generations discarded as burn-in. The maximum-likelihood analysis was performed under the GTR +GAMMA model and bootstrap resampling was applied to assess nodal support using the autoMRE criterion. To further examine relationships among COI haplotypes, we constructed a median-joining haplotype network using PopArt v. 1.7 (Leigh \& Bryant, 2015) and redrew it manually. Finally, we asked whether a phylogeny enforcing the monophyly of cave species was less likely than unconstrained topologies using a Shimodaira-Hasegawa test (Shimodaira, 2002), implemented in the phangorn package (Schliep, 2011) for R (R Development Core Team, 2018).

\section{RESULTS}

We analyzed 522 base pairs of the COI gene, of which 162 were variable (22 singletons, 140 parsimony-informative sites). Bayesian and maximum-likelihood analyses resulted in nearly identical topologies, showing that cave forms of Trichomycterus in Santander have evolved independently at least twice. One evolutionary event corresponds to Trichomycterus rosablanca, which was recovered with strong support (0.96 posterior probability, $72 \%$ maximum-likelihood bootstrap) as sister to Eremophilus mutisii, a species that lives in surface streams in the Bogotá River basin and has conspicuous eyes and shows profusely vermiculated dark coloration (Fig. 2, Clade 1). The second evolutionary event corresponded to a clade including the species T. sandovali and specimens from the Sogamoso River drainage, including surface populations and all the remaining cave species and populations analyzed (Fig. 2, Clade 2). Relationships among the clades including T. rosablanca and E. mutisii, T. sandovali and allies, and other species were not strongly supported, but the Shimodaira-Hasegawa test showed that unconstrained and constrained topologies differred significantly. The topology in which cave populations were monophyletic was less fit to the data than the unconstrained topology in which troglomorphic traits are homoplasious $(\mathrm{P}=0.002)$. We thus reject the hypothesis of a single origin for the evolution of cave-living and associated phenotypes (i.e. loss of eyes and pigmentation).

Not only did we find that cave populations referred to Trichomycterus sandovali are more closely allied to surface taxa than to the cave species T. rosablanca, but also that genetic divergence between cave-dwelling T. sandovali and other taxa from both surface streams and caves is shallow to non-existent. For example, we observed no genetic structure between cave and surface populations from Zapatoca: the surface population beared eyes and had a spotted to homogeneously dark coloration, whereas cave populations (one of them collected at the type locality of T. sandovali) had reduced eyes or lacked them and their coloration was faint. Moreover, there was no genetic structure between populations from Zapatoca and Los Santos (the latter collected close to the type locality of T. uisae Castellanos-Morales, 2008), which are separated by the deep Sogamoso River basin (Fig. 2; Clade 2). Likewise, cave and surface populations collected in Guadalupe and Guapotá (Suárez River drainage), and Curití (Fonce River drainage), differed only by two substitutions from those collected at the type locality of T. sandovali. The haplotype network for Clade 2 showed that cave and surface populations share haplotypes, suggesting recent divergence or gene flow (Fig. 2). Furthermore, we found no genetic differences in COI sequences between T. sandovali and two other cave species, namely "T. guacamayoensis" Ardila Rodríguez 2018 (recently 180 shown to be a junior synonym of T. latistriatus (Eigenmann, 1917); see DoNascimiento \& Prada-Pedreros, 2020) and T. uisae (Fig. 2).

Despite their geographic proximity to surface and cave populations from Santander, several surface taxa from our study area were more closely related to species from other regions (Fig. 2). The species Trichomycterus ruitoquensis Ardila Rodríguez, 2007, T. straminius (Eigenmann, 1917), and undescribed taxa recently collected 
in the Carare, Colorada, and Sogamoso rivers belonged to clades with species not occurring in Santander like $T$. striatus (Meek \& Hildebrand, 1913) (restricted to Costa Rica and Panamá) and T. banneaui (Eigenmann, 1912) (from tributiaries in the middle Magdalena basin, Department of Tolima, Colombia).

We obtained two additional unexpected results. First, our data revealed a potentially undescribed species in the La Iglesia surface stream in the city of Bucaramanga, Santander. Most of the specimens we collected at this locality corresponded genetically and morphologically to Trichomycterus ruitoquensis (Fig. 2, Clade 1). However, one of the individuals collected in the same stream differed genetically from T. ruitoquensis by five substitutions in COI and morphologically by an irregular spotted pattern (vs. regular in T. ruitoquensis). Second, we observed atypical coloration among some surface individuals collected in the Uchuval stream, near the Nitro and Alsacia caves in Zapatoca. Some individuals showed a homogeneously dark pigmentation, which differed from other individuals from the same stream exhibiting a spotted pigmentation pattern on the body (see photographs in Fig. 2).

\section{DISCUSSION}

Our study provides evidence for the repeated evolution of cave-living forms from surface ancestors in trichomycterid catfishes in a restricted geographic region in Colombia. At least two lineages (Trichomycterus rosablanca, T. sandovali and allies) colonized caves independently, and convergently evolved loss of eyes and body pigmentation in the karst region of Santander. These two lineages occur in separate drainages (Suárez and Carare rivers, respectively) not connected by river courses, further supporting the hypothesis that cave-living forms are derived from independent colonization events of subterranean environments in different areas. We lack DNA sequences from cave species of Trichomycterus from other countries in South America (Fig. 1A). However, the vast geographical distances separating them and overall congruence between geography and phylogeny in the group (Ochoa et al., 2017; Katz et al., 2018; Ochoa et al., 2020) suggests that species of Trichomycterus have independently colonized caves multiple times. In addition, it remains possible that cave species from Santander which we did not sample may have independently colonized these environments (Fig. 2). Examples include $T$. santanderensis Castellanos-Morales, 2007 from the Lebrija River drainage which we hypothesize belongs to the clade formed by T. sandovali and allies, and T. sketi Castellanos-Morales, 2011 which occurs in a separate drainage (Opón River) and may represent a distinct lineage.

Convergent evolution associated with cave living has been documented in other fish systems including Astyanax mexicanus (Dowling et al., 2002; Bradic et al., 2012), Garra barreimiae Fowler \& Steinitz 1956 (Kirchner et al., 2017), and amblyopsids (Niemiller et al., 2012). In all cases, cave-dweller fishes exhibit similar phenotypic traits including absence -or reduction- of eyes and body pigmentation, suggesting adaptation to cave environments along similar trajectories. More broadly, such pattern speaks to the repeatability of evolution by natural selection owing to common selective pressures and potentially to shared genetic and developmental constraints (Losos, 2017).

In addition to our finding of independent colonization of caves in Trichomycterus rosablanca and T. sandovali, our work raises the intriguing possibility that different populations closely allied to the latter (i.e. members of Clade 2) may have independently colonized and adapted to caves in drainages along the Sogamoso drainage. Genetic similarity and haplotype sharing between surface and cave populations in this clade suggests that these populations diverged recently, that they still experience gene flow, or both. Gene flow in these karstic systems is likely because water flows in and in some cases out of caves, potentially allowing dispersal of adult fishes, larvae, or eggs. This result is consistent with studies on other cave organisms (Astyanax mexicanus, Garra barreimiae, and cave salamanders) in which cave and surface populations are also connected by gene flow (Bradic et al., 2012; Niemiller et al., 2008; Kirchner et al., 2017), possibly due to sporadic flooding. Given genetic exchange between surface and cave environments, selective pressures strong enough to counteract the effects of migration are needed to account for phenotypic evolution in cavefishes (Cartwright et al., 2017). Accordingly, some studies suggest that divergence in the face of gene flow is a main driver of the evolution of cave-dwellers (Juan et al., 2010; Bradic et al., 2012). Limited genetic divergence between surface and cave populations is also consistent with scenarios in which the origin of cave phenotypes is initially promoted by phenotypic plasticity (Rohner et al., 2013; Bilandžija et al., 2019) or via epigenetic mechanisms (Gore et al., 2018). Future work extending our analyses to genome-wide assays of genetic variation will allow us to better characterize gene flow, elucidate 
relationships and estimate timing of divergence among populations, and assess the genetic basis of phenotypes in the system.

In addition to suggesting that caves were likely colonized repeatedly and that penotypic evolution in Trichomycterus may occur rapidly and with gene flow, our finding of no genetic differentiation in the COI gene between cave-dweller and surface populations in the T. sandovali group (Fig. 2, Clade 2) may have taxonomic implications. In particular, we found no genetic structure among populations currently assigned to T. sandovali, "T. guacamayoensis" (i.e. T. latistriatus) and T. uisae, and specimens from Guadalupe, Guapotá and Zapatoca municipalities. Although the populations we sampled are separated by up to nearly a couple hundred of kilometers and by deep canyons, and although some of them lack eyes and pigments while others have these traits, they all are genetically too similar to distinguish them using the mitochondrial marker we employed, which is often used as a barcode for species identification (Hebert et al., 2003; Ward et al., 225, 2009). While lack of COI divergence may simply reflect recent diversification or gene flow, an alternative interpretation is that T. sandovali might not correspond to a cavefish species restricted to the Alsacia cave in Zapatoca as traditionally believed, but rather to a taxon with much broader distribution consisting of hypogean and epigean populations throughout the Sogamoso River basin, much like the case of the Mexican Tetra (Bradic et al., 2012). A taxonomic review with careful attention to phenotypic variation is needed to assess the status of populations in the group as separate species and to identify several specimens included in our analyses which may correspond to undescribed species.

The importance of more extensive sampling to better understand patterns of cave colonization and evolution in our study system is illustrated by comparing our results to those implied by previous phylogenetic studies of trichomycterids. Based on work showing that two cave species lacking eyes and pigmentation (T. sandovali and T. rosablanca) occupied similar phylogenetic positions in analyses with partly overlapping — and incompletesampling (Mesa S. et al., 2018; Ochoa et al. 2017; Ochoa et al. 2020), it appeared likely that cave species from Santander had a single origin. Our phylogeny was generally congruent with trees based on thousands of loci including less taxa (Ochoa et al. 2017; Ochoa et al. 2020), yet only by sampling multiple additional populations we were able to determine (1) that T. sandovali and T. rosablanca belong to different clades, implying separate colonization of caves; and (2) that more than one event of cave colonization may have occurred among $T$. sandovali and its close relatives. Because multiple cave populations exist in the Santander karst region and remain unstudied, additional work has potential to reveal other examples of convergence associated with cave living.

Our finding of individuals with homogeneously dark pigmentation differing from other individuals in the same surface stream exhibiting a spotted pigmentation pattern is intriguing and requires further study. A potential explanation is that homogeneously pigmented individuals might be the result of re-colonizations of the surface environment from caves. Because cave-dweller populations are uniformly depigmented, individuals recolonizing the surface may have recovered dark pigmentation yet not in a spotted pattern likely lost following cave invasion. Although this scenario is speculative and would need to be tested, we note that cave fishes may be common exceptions to Dollo's law (Collin \& Miglietta, 2008), which argues that once a complex trait is lost it is very unlikely to be re-acquired. Although cave-dwellers have been considered evolutionary "dead-ends" (Stern et al., 2017) owing to their specialization to underground life involving the loss of eyes and pigmentation, evidence from several lineages of organisms adapted to caves including fishes (Dillman et al., 2011), salamanders (Trajano \& Cobolli, 2012), scorpions (Prendini et al., 2010), and amphipods (Copilaş-Ciocianu et al., 2018) indicates that reacquisition of surface phenotypes upon recolonization from caves is indeed possible.

To conclude, we have shown that trichomycterids from Santander have experienced convergent evolution as a likely consequence of repeated colonization of cave environments, and that such convergence has likely occurred in the face of gene flow and within a relatively restricted geographic area. More broadly, Trichomycterus from Santander have great potential for future studies addressing additional evolutionary, ecological, and developmental questions about processes leading to the extreme phenotypes that characterize cave-living. How does speciation occur in these organisms? What is the role of forces like selection, mutation, drift, and gene flow in trait evolution? What are the molecular, genetic, and developmental processes underlying the loss of complex organs such as eyes? How are cavefish populations genetically structured? What are the implications of population structure for their conservation? Our study has barely scratched the surface of what we anticipate to be a promising system to study these and many other questions. 


\section{ACKNOWLEDGEMENTS}

We are grateful to Yuranis Miranda, Alexandra Jiménez, Nataly Pimiento, Gerardo Bárcenas, Francisco Bautista, Diego González, and Cinthy Jimenez for help during field work; to Jorge Avendaño and Catalina Palacios for collaboration during lab work; and to Juan Gabriel Albornoz for support when visiting the IAVH-P collection. This project would have not been possible for JSF without the years of constant support of Graciela Flórez Villamizar; his efforts are dedicated to her. MT remembers that Javier Peña was the first to point to him those little white and eyeless fish when jointly exploring the Cueva del Nitro, Zapatoca, in the late 1990s. This research was supported by Fundación Iguaque, the Departamento de Ciencias Biológicas at Universidad de los Andes, and Santander Bio. Santander Bio was a project funded by the Sistema General de Regalías, administered by the Departamento Nacional de Planeación (BPIN 2017000100046), executed by the Gobernación de Santander, and operated by the Instituto de Investigación de Recursos Biológicos Alexander von Humboldt and the Universidad Industrial de Santander (Inter-administrative Agreement 2243, Gobernación de Santander). Specimens were collected under permits issued by ANLA (Resolution 004 of 2015) and by the Instituto de Investigación de Recursos Biológicos Alexander von Humboldt (Decree 1376 of 2013).

\section{REFERENCES}

Ardila-Rodríguez CA. 2006. Trichomycterus sandovali, (Siluriformes, Trichomycteridae) una nueva especie de pez cavernícola para el departamento de Santander-Colombia. Peces del departamento de Santander 2: $1-16$.

Ardila-Rodríguez CA. 2007. Trichomycterus ruitoquensis, (Siluriformes, Trichomycteridae) una nueva especie de pez de la cuenca alta del río Lebrija, departamento de Santander, Colombia. Peces del departamento de Santander 3: 1-16.

Ardila-Rodríguez CA. 2018. Trichomycterus guacamayoensis sp. nov. (Siluriformes, Trichomycteridae) una nueva especie de pez del río Suárez, cuenca media del Río Magdalena departamento de Santader - Colombia. Peces del departamento de Santander 11: 1-20.

Bichuette ME, Rizzato PP. 2012. A new species of cave catfish from Brazil, Trichomycterus rubbioli sp. n., from Serra do Ramalho karstic area, São Francisco River basin, Bahia State (Silurifomes: Trichomycteridae). Zootaxa 3480: 48-66.

Bilandžija H, Hollifield B, Steck M, Meng G, Ng M, Koch AD, Gračan R, Ćetković H, Porter ML, Renner KJ, Jeffery WR. 2019. Phenotypic plasticity as a mechanism of cave colonization and adaptation. bioRxiv 657460.

Bradic M, Beerli P, García-de León FJ, Esquivel-Bobadilla S, Borowsky RL. 2012. Gene flow and population structure in the Mexican blind cavefish complex (Astyanax mexicanus). BMC Evolutionary Biology 12: 9.

Blount ZD, Lenski RE, Losos JB. 2018. Contingency and determinism in evolution: replaying life's tape. Science 362: eaam5979.

Campos MR. 2017. Two new species of freshwater, cave-dwelling crabs of the genus Neostrengeria Pretzmann, 1965, from Colombia (Crustacea: Decapoda: Pseudothelphusidae). Zootaxa 4247: 157-164.

Cartwright RA, Schwartz RS, Merry AL, Howell MM. 2017. The importance of selection in the evolution of blindness in cavefish. BMC Evolutionary Biology 17: 45.

Castellanos-Morales CA. 2007. Trichomycterus santanderensis: A new species of troglomorphic catfish (Siluriformes, Trichomycteridae) from Colombia. Zootaxa 1541: 49-55.

Castellanos-Morales CA. 2008. Trichomycterus uisae: a new species of hypogean catfish (Siluriformes: Trichomycteridae) from the northeastern Andean Cordillera of Colombia. Neotropical Ichthyology 6: 307-314.

Castellanos-Morales CA. 2010. Trichomycterus sketi: a new species of subterranean catfish (Siluriformes: Trichomycteridae) from the Andean Cordillera of Colombia. Biota Colombiana 11: 33-41.

Castellanos-Morales CA. 2018. A new species of cave catfish, genus Trichomycterus (Siluriformes: Trichomycteridae), from the Magdalena River system, Cordillera Oriental, Colombia. Biota Colombiana 19: $117-130$. 
Castellanos-Morales CA, Marino-Zamudio LL, Guerrero-V. L, Maldonado-Ocampo JA. 2011. Peces del departamento de Santander, Colombia. Revista de la Academia Colombiana de Ciencias Exactas, Físicas y Naturales. 35: 189-212.

Castellanos-Morales CA, Galvis F. 2012. Species from the Trichomycterus (Siluriformes: Trichomycteridae) genus in Colombia. Boletín Científico. Centro de Museos. Museo de Historia Natural 16: 194-206.

Castellanos-Morales CA, Moreno F, Malagón, LM, Arango ÁJ, Pardo DD, Méndez MA. 2015. Aportes al conocimiento y uso de los ecosistemas subterráneos del municipio de La Paz (Santander). Boletín Científico. Centro de Museos. Museo de Historia Natural 19: 173-185.

Christiansen K. 2012. Morphological adaptations. In: Culver DC, White WB, eds. Encyclopedia of Caves. Amsterdam: Elsevier, 517-528.

Collin R, Miglietta MP. 2008. Reversing opinions on Dollo's Law. Trends in Ecology \&3 Evolution 23: 602-609.

Copilaş-Ciocianu D, Fišer C, Borza P, Petrusek A. 2018. Is subterranean lifestyle reversible? Independent and recent large-scale dispersal into surface waters by two species of the groundwater amphipod genus Niphargus. Molecular Phylogenetics and Evolution 119: 37-49.

Dillman CB, Bergstrom DE. Noltie DB, Holtsford TP, Mayden RL. 2011. Regressive progression, progressive regression or neither? Phylogeny and evolution of the Percopsiformes (Teleostei, Paracanthopterygii). Zoologica Scripta 40: 45-60.

DoNascimiento C, Herrera-Collazos EE, Herrera-R GA, Ortega-Lara A, Villa-Navarro FA, Usma-Oviedo JS, Maldonado-Ocampo JA. 2017. Checklist of the freshwater fishes of Colombia: a Darwin Core alternative to the updating problem. ZooKeys 708: 25-138.

DoNascimiento C, Prada-Pedreros S. 2020. A new troglomorphic species of Trichomycterus (Siluriformes: Trichomycteridae) from northeastern Colombia, with proposal of a new Trichomycterus subclade and remarks on some nominal species from Colombia. Journal of Fish Biology. Accepted Author Manuscript. doi: $10.1111 / \mathrm{jfb} .14286$.

Fricke R, Eschmeyer WN, Van der Laan R, eds. 2019. Eschmeyer's Catalog of Fishes: Genera, Species, References. Available at: http://researcharchive.calacademy.org/research/ichthyology/catalog/fishcatmain.asp (accessed 28 December 2019).

Hebert PDN, Cywinska A, Ball SL, Ward JR. 2003. Biological identifications through DNA barcodes. Proceedings of the Royal Society of London B: Biological Sciences 270: 313-321.

Herman A, Brandvain Y, Weagley J, Jeffery WR, Keene AC, Kono T J, Bilandžija H, Borowsky R, Espinasa L, O'Quin K, Ornelas-García CP, Yoshizawa M, Carlson B, Maldonado E, Gross JB, Cartwright RA, Rohner N, Warren WC, McGaugh SE. 2018. The role of gene flow in rapid and repeated evolution of cave-related traits in Mexican tetra, Astyanax mexicanus. Molecular Ecology 27: 4397-4416.

Edgar RC. 2004. MUSCLE: multiple sequence alignment with high accuracy and high throughput. Nucleic Acids Research 32: 1792-1797.

Espinasa L, Borowsky RB. 2001. Origins and relationship of cave populations of the blind Mexican tetra, Astyanax fasciatus, in the Sierra de El Abra. Environmental Biology of Fishes 62: 233-237.

Gaona-Narváez T. 2015. El Cretácico sedimentario al este de la Falla de San Jerónimo: Compilación para el Mapa Geológico de Colombia. In: Gómez-Tapia J, Almanza-Meléndez, MF (eds). Servicio Geogológico Colombiano, Publicaciones Geológicas Especiales 33: 421-429.

Gómez-Tapia J, Montes-Ramírez NE, Nivia-Guevara Á, Diederix H, eds. 2015. Mapa Geológico de Colombia 2015. Escala 1:1000000. Servicio Geológico Colombiano.

Gore A, Tomins K, Iben J, Ma L, Castranova D, Davis A, Davis A, Parkhurst A, Jeffery, W, Weinstein B. 2018. An epigenetic mechanism for cavefish eye degeneration. Nature Ecology 83 Evolution 2: 1155-1160.

Gross JB. 2012. The complex origin of Astyanax cavefish. BMC Evolutionary Biology 12: 105.

Gross JB, Meyer B, Perkins M. 2015. The rise of Astyanax cavefish. Developmental Dynamics 244: 1031-1038.

Huelsenbeck JP, Ronquist F. 2001. MRBAYES: Bayesian inference of phylogenetic trees. Bioinformatics 17: 754755 .

Jeffery WR. 2001. Cavefish as a model system in evolutionary developmental biology. Developmental Biology 231: 1-12.

Jeffery WR. 2009. Evolution and development in the cavefish Astyanax. Current Topics in Developmental Biology 86: 191-221.

Juan C, Guzik, MT, Jaume D, Cooper SJ. 2010. Evolution in caves: Darwin's 'wrecks of ancient life' in the molecular era. Molecular Ecology 19: 3865-3880. 
Katz AM, Barbosa MA, Mattos JLO, Costa WJEM. 2018. Multigene analysis of the catfish genus Trichomycterus and description of a new South American trichomycterine genus (Siluriformes, Trichomycteridae). Zoosystematics and Evolution 94: 557-566.

Kearse M, Moir R, Wilson A, Stones-Havas S, Cheung M, Sturrock S, Buxton A, Markowitz S, Duran C, Thierer T, Aston B, Meintjes P, Drummond A. 2012. Geneious Basic: an integrated and extendable desktop software platform for the organization and analysis of sequence data. Bioinformatics 28: 1647-1649.

Kirchner S, Sattmann H, Haring E, Plan L, Victor R, Kruckenhauser L. 2017. Investigating gene flow between the blind cavefish Garra barreimiae and its conspecific surface populations. Scientific Reports 7: 5130.

Kowalko JE, Rohner N, Rompani SB, Peterson BK, Linden TA, Yoshizawa M, Kay EH, Weber J, Hoekstra HE, Jeffery WR, Borowsky R, Tabin CJ. 2013. Loss of schooling behavior in cavefish through sightdependent and sight-independent mechanisms. Current Biology 23: 1874-1883.

Lanfear R. Calcott B, Ho SY, Guindon S. 2012. PartitionFinder: combined selection of partitioning schemes and substitution models for phylogenetic analyses. Molecular Biology and Evolution 29: 1695-1701.

Leigh JW, Bryant D. 2015. PopArt: full-feature software for haplotype network construction. Methods in Ecology and Evolution 6: 1110-1116.

Losos JB. 2017. Improbable destinies. Fate, chance, and the future of evolution. New York: Riverhead Books.

Mesa LM, Lasso CA, Ochoa LE, DoNascimiento, C. 2018. Trichomycterus rosablanca (Siluriformes, Trichomycteridae) a new species of hipogean catfish from the Colombian Andes. Biota Colombiana 19: 95-116.

Mendoza JE, Murillo JMM, Orjuela GR. 2009. Sistema Cárstico de la Formación Rosablanca Cretácico inferior, en la provincia santandereana de Vélez, Colombia. Geología Colombiana 34: 35-44.

Moran D, Softley R, Warrant EJ. 2015. The energetic cost of vision and the evolution of eyeless Mexican cavefish. Science Advances 1: e1500363.

Muñoz-Saba Y, González-Sánchez I, Calvo-Roa N, eds. 2013. Cavernas de Santander, Colombia: guía de campo. Bogotá: Universidad Nacional de Colombia.

Niemiller ML, Fitzpatrick BM, Miller BT. 2008. Recent divergence with gene flow in Tennessee cave salamanders (Plethodontidae: Gyrinophilus) inferred from gene genealogies. Molecular Ecology 17: 2258-2275.

Niemiller ML, Near TJ, Fitzpatrick BM. 2012. Delimiting species using multilocus data: diagnosing cryptic diversity in the southern cavefish, Typhlichthys subterraneus (Teleostei: Amblyopsidae). Evolution 66: 846-866.

Niemiller ML, Bichuette ME, Chakrabarty P, Fenolio DB, Gluesenkamp AG, Soares D, Zhao Y. 2019. Chapter 27 - Cavefishes. In White WB, Culver DC, Pipan T, eds. Encyclopedia of Caves (Third Edition). Cambridge: Academic Press, 227-236.

Ochoa LE, Roxo FF, DoNascimiento C, Sabaj MH, Datovo A, Alfaro M, Oliveira C. 2017. Multilocus analysis of the catfish family Trichomycteridae (Teleostei: Ostariophysi: Siluriformes) supporting a monophyletic Trichomycterinae. Molecular Phylogenetics and Evolution 115: 71-81.

Ochoa LE, Datovo A, DoNascimiento C, Roxo FF, Sabaj MH, Chang J, Melo BF, Silva GSC, Foresti F, Alfaro M, Oliveira C. 2020. Phylogenomic analysis of trichomycterid catfishes (Teleostei: Siluriformes) inferred from ultraconserved elements. Scientific Reports 10: 2697.

Prendini L, Francke OF, Vignoli V. 2010. Troglomorphism, trichobothriotaxy and typhlochactid phylogeny (Scorpiones, Chactoidea): more evidence that troglobitism is not an evolutionary dead-end. Cladistics 26: $117-142$.

Proudlove, G. S. 2010. Biodiversity and distribution of the subterranean fishes of the world. In Trajano E, Bichuette ME, Kapoor BG, eds. Biology of Subterranean Fishes. Boca Raton: CRC Press, 41-63.

Riddle MR, Aspiras AC, Gaudenz K, Peuß R, Sung JY, Martineau B, Peavey M, Box AC, Tabin JA, McGaugh S, Borowsky R, Tabin CJ, Rohner N. 2018. Insulin resistance in cavefish as an adaptation to a nutrientlimited environment. Nature 555: 647-651.

Romero A. 2011. The evolution of cave life. American Scientist 99: 144-155

Rohner N, Jarosz DF, Kowalko JE, Yoshizawa M, Jeffery WR, Borowsky RL, Lindquist S, Tabin CJ. 2013. Cryptic variation in morphological evolution: HSP90 as a capacitor for loss of eyes in cavefish. Science 342: 1372-1375.

Shimodaira H. 2002. An approximately unbiased test of phylogenetic tree selection. Systematic Biology 51: 492508.

Stamatakis A. 2014. RAxML version 8: a tool for phylogenetic analysis and post-analysis of large phylogenies. Bioinformatics 30: 1312-1313. 
Stern DB, Breinholt J, Pedraza-Lara C, López-Mejía M, Owen CL, Bracken-Grissom H, Fetzner JW, Crandall KA. 2017. Phylogenetic evidence from freshwater crayfishes that cave adaptation is not an evolutionary deadend. Evolution 71: 2522-2532.

Torres M, Quiñones C, eds. 2019. Santander Bio: Resultados, Retos y Oportunidades. Bogotá: Instituto de Investigación de Recursos Biológicos Alexander von Humboldt.

Trajano E, Cobolli M. 2012. Evolution of lineages. In: White WB, Culver DC, eds. Encyclopedia of caves. Oxford: Academic Press, 295-304.

Wasko AP, Martins C, Oliveira C, Foresti F. 2003. Non-destructive genetic sampling in fish. An improved method for DNA extraction from fish fins and scales. Hereditas 138: 161-165.

Ward RW, Zemlak TS, Innes BH, Last PR, Hebert PDN. 2005. DNA barcoding Australia's fish species. Philosophical Transactions of the Royal Society of London B: Biological Sciences 360: 1847-1857.

Ward RD, Hanner R, Hebert PDN. 2009. The campaign to DNA barcode all fishes, FISH-BOL. Journal of Fish Biology 74: 329-356.

Yoshizawa M, Gorički Š, Soares D, Jeffery WR. 2010. Evolution of a behavioral shift mediated by superficial neuromasts helps cavefish find food in darkness. Current Biology 20: 1631-1636. 
Table 1. Cave and surface populations of Trichomycterus sampled for this study.

\begin{tabular}{|c|c|c|c|c|c|c|}
\hline Terminal taxon & Habitat & $\begin{array}{l}\text { Cave } \\
\text { phenotype }\end{array}$ & $\begin{array}{l}\text { Catalog } \\
\text { number }\end{array}$ & Locality & $\begin{array}{l}\text { Geographic } \\
\text { coordinates }\end{array}$ & $\begin{array}{l}\text { GenBank/BOLD } \\
\text { accession codes }\end{array}$ \\
\hline Bullockia maldonadoi & Surface & no & LBP3112 & La Laja, Biobio, Chile & $-37.2152,-72.4469$ & KY857926.1 \\
\hline Cambeva davisi & Surface & no & LBP7130 & Paranapanema, Brazil & & KY857988.1 \\
\hline Cambeva diatropoporos & Surface & no & LBP14694 & Jacuí, Laguna dos Patos, Brazil & & KY857996.1 \\
\hline Cambeva zonata & Surface & no & LBP2653 & Ribeira de Iguape, Atlantic, Brazil & $-24.6866,--48.9945$ & KY857986.1 \\
\hline Copionodon pecten & Surface & no & LBP2653 & Paraguaçu, Atlantic, Brazil & & KY857986.1 \\
\hline Eremophilus mutissii & Surface & no & ANSP11306 & Magdalena drainage, Colombia & & KY857931.1 \\
\hline Ituglanis goya & Surface & no & LBP17131 & das Almas, Tocantins, Brazil & $-13.7551,-47.4555$ & KY857945.1 \\
\hline Ituglanis ramiroi & Surface & no & LBPV-63262 & Paranã, Tocantins, Brazil & & KY857998.1 \\
\hline Ituglanis eichorniarum & Surface & no & LBP4686 & Paraguay, Paraná, Brazil & $-14.6955,-57.2597$ & KY857939.1 \\
\hline Nematogenys inermis & Surface & no & LBP3105 & Concepción, Chile & & KY857952.1 \\
\hline Scleronema angustirostre & Surface & no & LBP13185 & Laguna dos Patos, Atlantic, Brazil & & KY857962.1 \\
\hline Scleronema minutum & Surface & no & LBP3310 & Laguna dos Patos, Atlantic, Brazil & & KY857957.1 \\
\hline Trichomycterus banneaui & Surface & no & LBP19537 & Magdalena drainage, Colombia & & KY858001.1 \\
\hline Trichomycterus cachiraensis & Surface & no & LBP19832 & Galvanes, Magdalena drainage, Colombia & $7.70626,-73.0359$ & KY857971.1 \\
\hline Trichomycterus guianensis & Surface & no & LBP17444 & Potaro, Essequibo, Guyana & $5.33777,-59.5658$ & KY857974.1 \\
\hline Trichomycterus itatiayae & Surface & no & LBP16356 & Paraiba do Sul, Atlantic, Brazil & & KY857977.1 \\
\hline Trichomycterus knerii & Surface & no & LBP18717 & Meta, Orinoco drainage, Colombia & $3.88101,-73.7822$ & KY857987.1 \\
\hline Trichomycterus punctulatus & Surface & no & ANSP180733 & Pisco, Pacific, Perú & $-13.6666,-75.7716$ & KY857983.1 \\
\hline Trichomycterus piratymbara & Surface & no & LBP9004 & Grande, Paraná, Brazil & $-20.6237,-46.2304$ & KY857970.1 \\
\hline Trichomycterus reinhardti & Surface & no & LBP16302 & Paraopeba, São Francisco, Brazil & $-20.1945,-44.1014$ & KY857997.1 \\
\hline Trichomycterus rosablanca & Cave & yes & 0502-I & Sardinas cave, Carare River drainage, El Peñón & $6.09333,-73.8285$ & MH407228.1 \\
\hline Trichomycterus ruitoquensis & Surface & no & LBP19838 & Rio Frio, Magdalena drainage, Colombia & $7.06902,-73.0704$ & KY857984.1 \\
\hline Trichomycterus sandovali & Cave & yes & LBP19833 & Magdalena drainage, Colombia & $6.80375,-73.2730$ & KY857985.1 \\
\hline Trichomycterus spilosoma & Surface & no & LBP19339 & Pacific, Ecuador & & KY857942.1 \\
\hline Trichomycterus straminius & Surface & no & LBP19834 & Manco River, Sogamoso River drainage, Piedecuesta & $6.84947,-72.9886$ & KY858006.1 \\
\hline
\end{tabular}


Trichomycterus striatus

Trichomycterus trasandianus

Trichogenes longipinnis

Trichomcyterus aff. trasandianus IAvH-P

17683

Trichomycterus areolatus

Trichomycterus calai IAvH-P 17803

Trichomycterus cf. mogotensis IAvH-P 21069

Trichomycterus sp. Curití ID 422

Trichomycterus sp. Curití ID 425

Trichomycterus sp. Curití ID 426

Trichomycterus latistriatus

("guacamayoensis")

Trichomycterus ruitoquensis IAvH-P 12397

Trichomycterus ruitoquensis ID 02 La Iglesia

Trichomycterus ruitoquensis ID 03 La Iglesia

Trichomycterus ruitoquensis ID 04 La Iglesia

Trichomycterus ruitoquensis ID 05 La Iglesia

Trichomycterus sandovali ID 402

Trichomycterus sandovali ID 403

Trichomycterus sandovali ID 404

Trichomycterus sp. Carare IAvH-P 20905

Trichomycterus sp. Carare IAvH-P 20978

Trichomycterus sp. Guadalupe ID 410

Trichomycterus sp. Guadalupe ID 411

Trichomycterus sp. Guadalupe ID 413

Trichomycterus sp. Guadalupe ID 414

Trichomycterus sp. Guadalupe ID 416
Surface no

Surface no

Surface no

Surface no

Surface no

Surface no

Surface no

Cave no

Cave no

Cave no

Cave no

Surface no

Surface

Surface

Surface

Surface

Cave

Cave

Cave

Surface

Surface

Surface

Surface

Surface

Cave

cave $\begin{array}{ll}\text { LBP19846 } & \text { Magdalena, drainage, Colombia } \\ \text { LBP19844 } & \text { Magdalena, drainage, Colombia }\end{array}$

LBP3862 Camburi, Atlantic, Brazil

Colorada River drainage, vereda La Belleza, Carmen de

IAvH-P 17683 Chucurí

LBP3118 Tolten, Pacific, Chile

IAvH-P 17803 Carare River drainage, Cimitarra

Umpalá River, Chicamocha River drainage, Santa

IAvH-P 21069 Bárbara

JSF422 Vaca cave, Fonce River drainage, Curití

JSF425 Vaca cave, Fonce River drainage, Curití

JSF426 Vaca cave, Fonce River drainage, Curití

CBIHS010-17 Los Aviones cave, Suárez River drainage, Guadalupe

IAvH-P 12397 Río Negro, Rionegro

Iglesia stream, Lebrija River drainage, Pan de Azúcar, Bucaramanga

Iglesia stream, Lebrija River drainage, Pan de Azúcar,

Bucaramanga

Iglesia stream, Lebrija River drainage, Pan de Azúcar,

Bucaramanga

Iglesia stream, Lebrija River drainage, Pan de Azúcar,

Bucaramanga

JSF05

JSF402

JSF 403

Alsacia cave, Suárez River drainage, Zapatoca

JSF404

Alsacia cave, Suárez River drainage, Zapatoca

IAvH-P 20978 Carare River drainage, Cimitarra

JSF 410

JSF411

JSF 413

JSF414

JSF 416
Coca stream, Suárez River drainage, Guadalupe

Coca stream, Suárez River drainage, Guadalupe

Coca stream, Suárez River drainage, Guadalupe

Berraco cave, Suárez River drainage, Guadalupe

Berraco cave, Suárez River drainage, Guadalupe
KY858003.1

KY858004.1

$-23.3518,-44.7635$

KY857961.1

$6.55800,-73.55900$

SBIOF015-19

KY857964.1

$6.58200,-73.59330$

$6.91303,-72.94260$

$6.60458,-73.07350$

$6.60458,-73.07350$

$6.60458,-73.07350$

6.21789, -73.41890

$6.11954,-74.22620$

7.11537, -73.09845

7.11537, - -73.09845

7.11537, - -73.09845

7.11537, -73.09845

$6.79839,-73.25728$

$6.79839,-73.25728$

$6.79839,-73.25728$

$6.43868,-74.13230$

$6.11954,-74.22620$

$6.19471,-73.41343$

$6.19471,-73.41343$

6.19471, -73.41343

$6.19802,-73.41380$

$6.19802,-73.41380$ 
Trichomycterus sp. Guapotá ID 417

Trichomycterus sp. Guapotá ID 420

Trichomycterus sp. Guapotá ID 421

Trichomycterus sp. La Colorada IAvH-P

17686

Trichomycterus sp. La Colorada IAvH-P

17716

Trichomycterus sp. La Colorada IAvH-P

17723

Trichomycterus sp. La Colorada IAvH-P

17734

Trichomycterus sp. Sogamoso IAvH-P20797

Trichomycterus sp. Zapatoca ID 06

Trichomycterus sp. Zapatoca ID 07

Trichomycterus sp. Zapatoca ID 08

Trichomycterus sp. Zapatoca ID 09

Trichomycterus sp. Zapatoca ID 10

Trichomycterus sp. Zapatoca ID 408

Trichomycterus sp. Zapatoca ID 409

Trichomycterus sp. ID 01 La iglesia

Trichomycterus uisae ID 427

Trichomycterus uisae ID 428

Trichomycterus uisae ID 429

Trichomycterus uisae ID 430

Trichomycterus uisae ID 431

Trichomycterus uisae ID 433

Trichomycterus uisae ID 435

\begin{tabular}{|c|c|c|c|c|c|}
\hline Cave & yes & JSF417 & Ojo de Agua cave, Suárez River drainage, Guapotá & $6.30815,-73.32090$ & \\
\hline Cave & yes & JSF420 & Ojo de Agua cave, Suárez River drainage, Guapotá & $6.30815,-73.32090$ & \\
\hline Cave & yes & JSF421 & $\begin{array}{l}\text { Ojo de Agua cave, Suárez River drainage, Guapotá } \\
\text { La Cristalina stream, Colorada River drainage, Carmen }\end{array}$ & $6.30815,-73.32090$ & \\
\hline Surface & no & IAvH-P 17686 & $\begin{array}{l}\text { de Chucurí } \\
\text { Cascajales river, Colorada River drainage, Carmen de }\end{array}$ & $6.55697,-73.55370$ & SBIOF020-19 \\
\hline Surface & no & IAvH-P 17716 & Chucurí & $6.59519,-73.57340$ & SBIOF024-19 \\
\hline Surface & no & IAvH-P 17723 & $\begin{array}{l}\text { La Danta stream, Colorada River drainage, Carmen de } \\
\text { Chucurí } \\
\text { La Concordia stream, Colorada River drainage, Carmen }\end{array}$ & $6.58036,-73.57130$ & SBIOF027-19 \\
\hline Surface & no & IAvH-P 17734 & de Chucurí & $6.58200,-73.59330$ & SBIOF030-19 \\
\hline Surface & no & IAvH-P20797 & Magdalena River basin, Barrancabermeja & $7.16718,-73.63080$ & SBIOF081-19 \\
\hline Cave & yes & JSF06 & Nitro cave, Suárez River drainage, Zapatoca & $6.80313,-73.27282$ & \\
\hline Cave & yes & JSF07 & Nitro cave, Suárez River drainage, Zapatoca & $6.80313,-73.27282$ & \\
\hline Cave & yes & JSF08 & Nitro cave, Suárez River drainage, Zapatoca & $6.80313,-73.27282$ & \\
\hline Cave & yes & JSF09 & Nitro cave, Suárez River drainage, Zapatoca & $6.80313,-73.27282$ & \\
\hline Cave & yes & JSF10 & Nitro cave, Suárez River drainage, Zapatoca & $6.80313,-73.27282$ & \\
\hline Surface & no & JSF408 & Uchuval stream, Sogamoso River drainage, Zapatoca & $6.80594,-73.26463$ & \\
\hline Surface & no & JSF409 & $\begin{array}{l}\text { Uchuval stream, Sogamoso River drainage, Zapatoca } \\
\text { Iglesia stream, Lebrija River drainage, Pan de Azúcar, }\end{array}$ & $6.80594,-73.26463$ & \\
\hline Surface & no & JSF01 & Bucaramanga & 7.11537, -73.09845 & \\
\hline Cave & no & JSF427 & Petroglifos cave, Sogamoso River drainage, Los Santos & $6.81385,-73.10935$ & \\
\hline Cave & no & JSF428 & Petroglifos cave, Sogamoso River drainage, Los Santos & $6.81385,-73.10935$ & \\
\hline Cave & no & JSF429 & Petroglifos cave, Sogamoso River drainage, Los Santos & $6.81385,-73.10935$ & \\
\hline Cave & no & JSF430 & Petroglifos cave, Sogamoso River drainage, Los Santos & $6.81385,-73.10935$ & \\
\hline Cave & no & JSF431 & Acuarela cave, Sogamoso River drainage, Piedecuesta & $6.87845,-73.04520$ & \\
\hline Cave & no & JSF433 & Acuarela cave, Sogamoso River drainage, Piedecuesta & $6.87845,-73.04520$ & \\
\hline Cave & no & JSF435 & Acuarela cave, Sogamoso River drainage, Piedecuesta & $6.87845,-73.04520$ & \\
\hline
\end{tabular}




\section{Figure Legends}

Figure 1. Type localities of cave species of Trichomycterus in the Neotropical region (top left), photograph showing an example of habitats occupied by fishes in this system (Las Sardinas Cave, the type locality of $T$. rosablanca; photo by Felipe Villegas), and map of the Department of Santander showing the collection sites of specimens of Trichomycterus analyzed in this study (bottom). Triangles correspond to caves, circles to surface streams. Orange triangles correspond to cave localities where fishes show reduced eyes and coloration, and blue triangles to caves where fishes have regular eyes and coloration. Cave localities are designated with letter $\mathrm{C}$ and surface streams with letter S. The type localities of cave species T. rosablanca (Cs) and T. sandovali (Cal) are indicated with asterisks.

Figure 2. Relationships among catfish in Trichomycterus and other genera reveal repeated colonization of caves and phenotypic convergence in the karst region of Santander, Colombia. The Bayesian gene tree on the left is an overview of phylogeny based on sequences of the COI gene (outgroups not shown). Colors at the tips indicate whether specimens were collected in the western slope of the Eastern Andes of Santander, whether they were found in cave habitats, and whether they lacked eyes or body pigmentation (i.e. troglomorphism). Strongly supported nodes (posterior probability $\geq 0.95$, maximum-likelihood bootstrap $\geq 70 \%$ ) relevant to the phylogenetic position of specimens from Santander are indicated with circles; numbered nodes are mentioned in the text and in panels on the right. Node 1 defines a clade formed by phenotypically contrasting species from caves in Santander (T. rosablanca) and surface streams in the Bogotá River basin (Eremophilus mutisii). Node 2 defines a large clade for which genealogical relationships are shown on the right with a median-joining network. Rectangles correspond to haplotypes and circles to individuals, with colors indicating whether or not specimens lacked eyes or pigmentation following the color scheme in the phylogeny; upper-case letters indicate habitat $(\mathrm{C}=$ cave, $\mathrm{S}=$ surface) and lower-case letters define localities. Note that all specimens differ at most by two substitutions in COI, that individuals sharing two of the haplotypes occur in multiple localities including both caves and surface streams, and that haplotypes are not consistently associated with phenotypes. The most common haplotype occurred both in caves and surface streams, and was shared by individuals with various phenotypes and by populations assigned to at least three different species: T. sandovali, T. uisae, and "T. guacamayoensis" (i.e. T. latistriatus). Finally, node 3 defines a clade from Santander more closely allied to species from other regions in the Neotropics than to taxa from the karst region; photographs of live fishes illustrate differences in phenotype between specimens from the same surface stream which also differed genetically, highlighting a potentially undescribed species. The panel on the bottom illustrates two species from cave habitats in Santander lacking eyes and pigmentation which we were unable to sample and may represent other instances of convergence. Photographs by the authors and by Felipe Villegas (T. rosablanca), Cesar Castellanos ( $T$. santanderensis and T. sketi), and from DoNascimiento et al. (2014; E. mutisii). 
bioRxiv preprint doi: https://doi.org/10.1101/2020.02.25.955179; this version posted February 26, 2020. The copyright holder for this preprint (which was not certified by peer review) is the author/funder, who has granted bioRxiv a license to display the preprint in perpetuity. It is made available under aCC-BY-NC 4.0 International license.

\section{Figure 1}
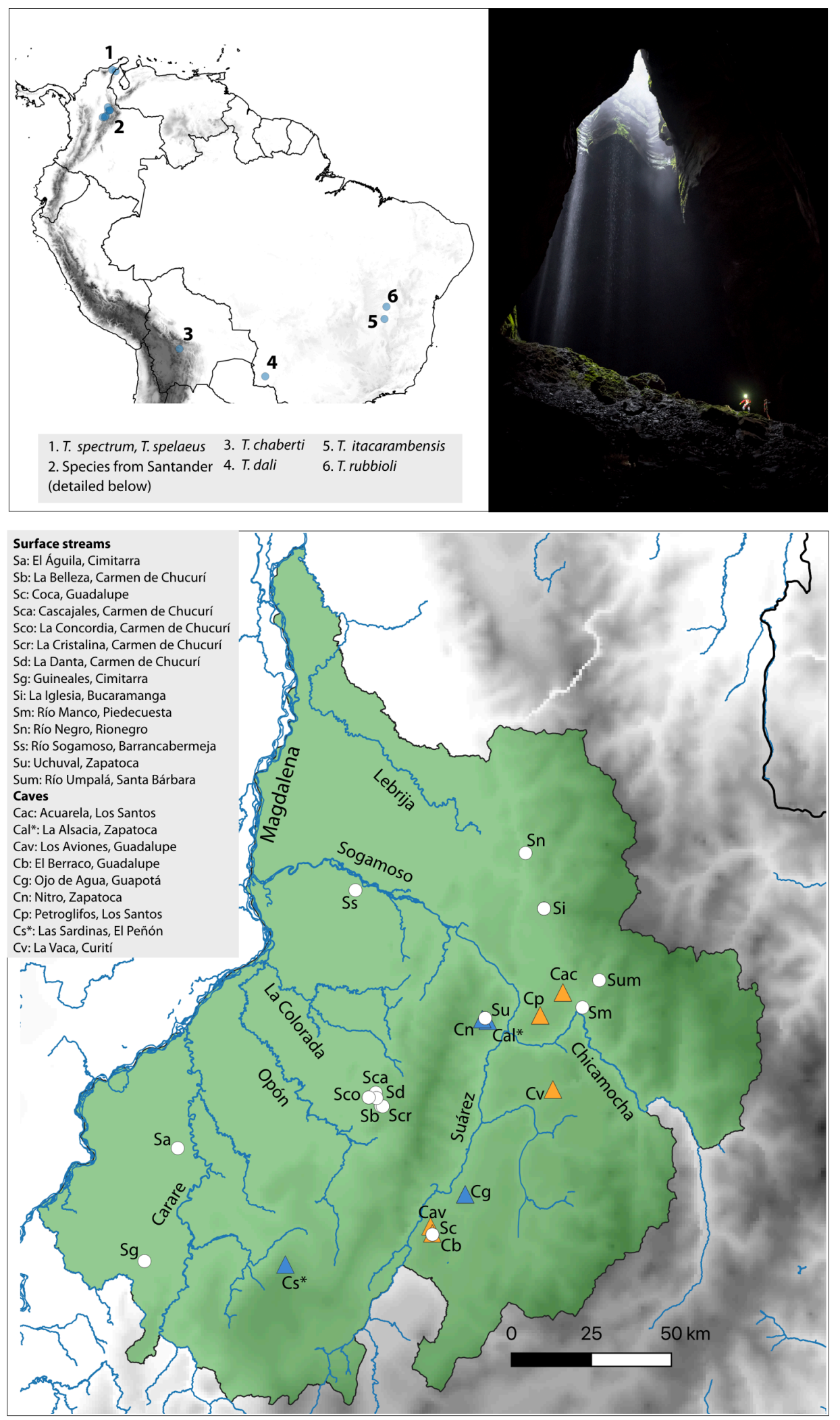
bioRxiv preprint doi: https://doi.org/10.1101/2020.02.25.955179; this version posted February 26, 2020. The copyright holder for this preprint (which was not certified by peer review) is the author/funder, who has granted bioRxiv a license to display the preprint in perpetuity. It is made available under aCC-BY-NC 4.0 International license.

\section{Figure 2}

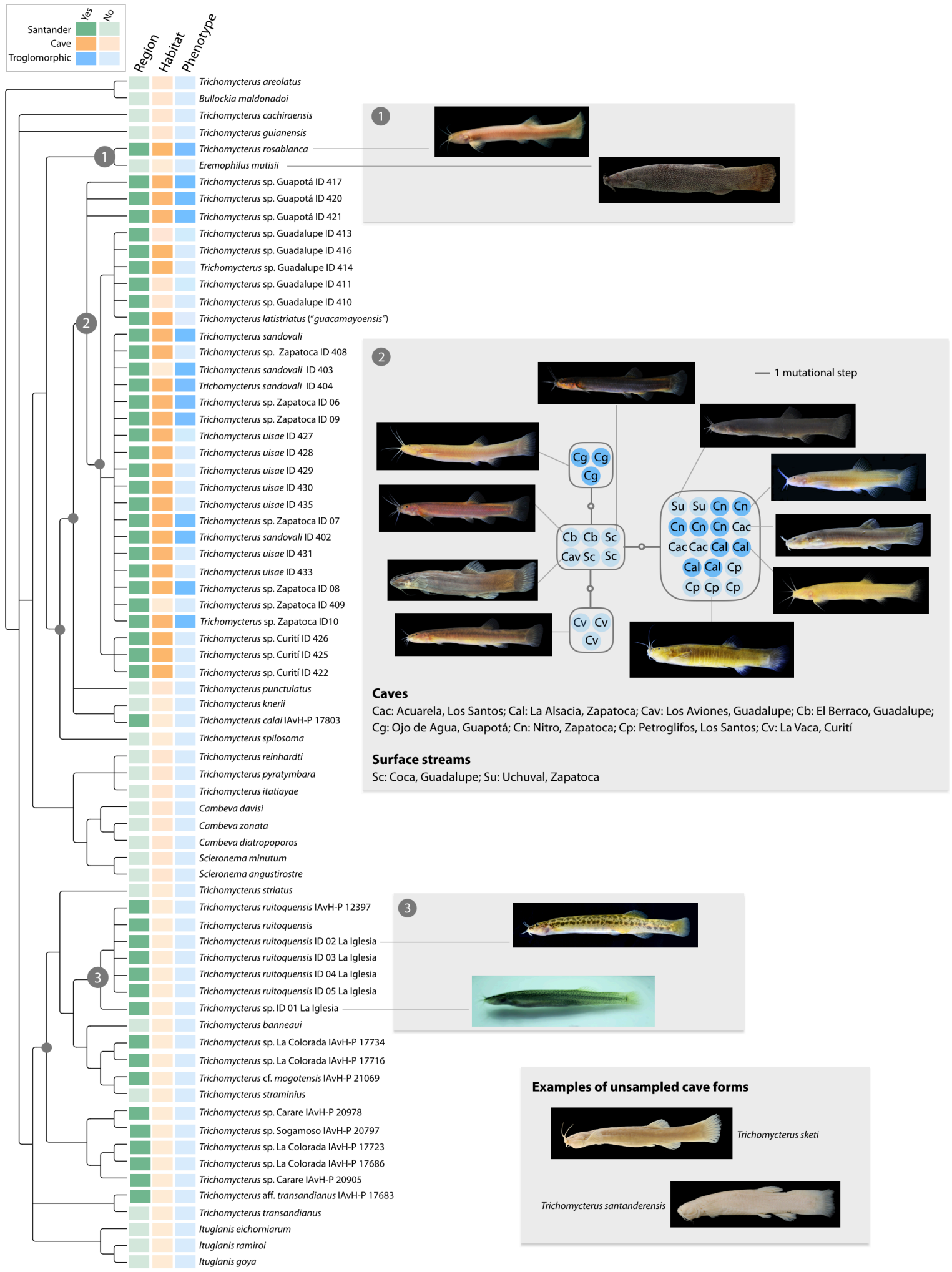

